\title{
Effectiveness of Xenograft and Porcine-Derived Resorbable Membrane in Augmentation of Posterior Extraction Sockets with a Severe Wall Defect. A Radiographic/Tomographic Evaluation
}

\author{
Renzo Guarnieri ${ }^{1}$, Dario Di Nardo ${ }^{1}$, Gianni Di Giorgio ${ }^{1}$, Gabriele Miccoli ${ }^{1}$, Luca Testarelli ${ }^{1}$ \\ ${ }^{1}$ Department of Dental and Maxillofacial Sciences, School of Dentistry, University La Sapienza, Rome, Italy.
}

\author{
Corresponding Author: \\ Renzo Guarnieri \\ Via L. Cattarin 3D, 31100 Treviso \\ Country \\ Phone: +393425224458 \\ E-mail: renzoguarnieri@gmail.com
}

\begin{abstract}
Objectives: The aim of the present prospective study was to evaluate, by means of intraoral periapical radiographs and conebeam computed tomography, hard tissue changes after ridge augmentation procedures in posterior extraction sockets with severe wall defects.

Material and Methods: Twenty patients, with a non-restorable premolar/molar tooth and severe wall defect, were enrolled in the present study, and underwent single-tooth extraction. Extraction sites were grafted with porcine-derived bone covered by porcine-derived collagen membrane. Intraoral periapical radiographs and cone-beam computed tomography scans, obtained at enrolment, and 6 months after ridge augmentation procedures were analysed and compared.

Results: In the intraoral periapical radiographs, mean vertical bone gains detected at the distal, central and mesial aspects of the extraction sockets were 3.5 (SD 1.1) $\mathrm{mm}, 8.2$ (SD 2.1) mm, and 3.9 (SD 1.7) $\mathrm{mm}$, respectively. In the cone-beam computed tomography scans, the mean vertical bone gains detected at the more vestibular and more palatal aspects were 4.4 (SD 1.9) $\mathrm{mm}$, and 3.3 (SD 2.8) $\mathrm{mm}$, respectively. The mean horizontal bone gain was 3.5 (SD 1.6) $\mathrm{mm}$. In all examined defects, mean vertical and horizontal bone levels showed a statistically significant increase $(\mathrm{P}<0.05)$ at 6 months after extraction.

Conclusions: Within the limits of this study, the results suggest that porcine-derived bone graft covered by a collagen membrane can support significant vertical and horizontal bone gain at posterior post-extraction sockets with severe wall defects.
\end{abstract}

Keywords: alveolar ridge augmentation; bone regeneration; bone substitutes; cone-beam computed tomography.

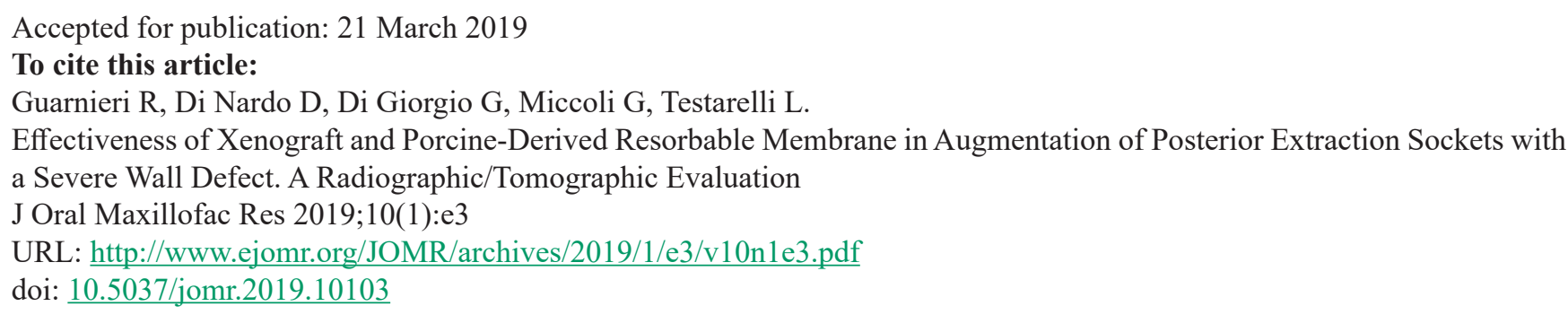




\section{INTRODUCTION}

Experimental studies in human showed that the spontaneous reabsorption and remodelling processes involved in bone healing after tooth extraction are responsible for dimensional reduction of the residual ridge with a reported average of 3 to $5 \mathrm{~mm}$ in width, and 0.4 to $3.9 \mathrm{~mm}$ in height after 6 months $[\underline{1}, \underline{2}]$. Moreover, in presence of periodontal and endodontic lesions, and/ or root fractures, the immunologic response to continuous antigenic stimulation from the root canal or periodontal pocket, creates a chronic inflammatory process, which often results in bone loss prior to and after tooth removal [ $\underline{3}]$. To counteract the post-extraction alveolar volume loss, different ridge augmentation techniques (RPTs) have been proposed [4-12]. Most of the techniques consist of filling the alveolar socket with different grafting materials with and without sealing the socket with absorbable or non-absorbable membranes. A recent literature review [12] on RPTs indicated that membranes alone might improve normal wound healing in extraction sites. The use of membrane alone, translated by the concept of guided bone regeneration, is aimed to prevent soft tissues from filling the osseous defect, and to allow the cells with osteogenic potential to colonize the wound [13]. However, in extraction sockets with a severe wall defect and poor volumetric bone support, the use of resorbable membranes alone is still questionable. The lack of stiffness and space making properties are a concern. In these cases, to provide a mechanical support to the absorbable membranes during the healing phase, graft materials are indicated [4-12].

The ideal resorbable membrane for RPTs should exhibit characteristics such as biocompatibility, dimensional stability, tissue integration at the defect site, and should act as a barrier to prevent soft tissue ingrowth $[\underline{14}, 15]$. Appropriate resorption time of the membrane is also important, since reabsorption before new bone formation may cause loss of dimensional stability, dissipation of bone substitute, and impaired healing at the defect site $[14,15]$.

Controversies exist in the literature on the graft material of choice $[16,17]$. The ideal graft material should minimize the ridge remodelling, and promote bone formation as fast as possible to shorten treatment time. Autogenous bone has always been the "gold standard" for grafting procedures [18,19]. However, its disadvantages include limited amount of available graft, additional surgical site, donor site morbidity, and requirement for general anaesthesia in the case of extraoral bone harvesting [20]. Alternatively, xenogenic bone has become a widely used biomaterial in RPTs, and has been supported by a number of publications [10]. Among the xenogenic bone grafts, porcine-derived bone has been recently evaluated for bone regeneration [21-25]. Porcine-derived bone has shown excellent osteoconductive properties without adverse reactions or inflammatory responses $[21,22-$ 28]. However, controversy remains whether it is truly resorbable, and whether the presence of residual graft particles could interfere with the healing process of bone. Since residual graft particles can be almost completely incorporated and surrounded by vital bone, several authors $[\underline{21}, \underline{26}, \underline{29}, \underline{30}]$ suggested that, once the biomaterial particles are embedded in mineralized tissue, they create a dense and hard tissue network similar to the host bone, providing biologic support.

The hypothesis to be tested in the present study is to determine if significant vertical and horizontal bone gain might be obtained in posterior extraction sites with severe wall defects, treated with porcine-derived bone graft, and covered by porcine-derived collagen membrane.

The objective is to radiographically/topographically analyse and compare the vertical and horizontal alveolar dimensions before and 6 month post RPT.

\section{MATERIAL AND METHODS}

Public domain online software (Raosoft, http:// www.raosoft.com/samplesize.html) was used to calculate the minimal number necessary for statistical evaluation. Twenty patients, requiring extraction of a single premolar or molar tooth and interested in receiving a dental implant, were enrolled in the study between September 2016 and December 2016. The study was approved by the Research Ethics Committee of the La Sapienza University of Rome (\#4597). Patients gave written consent, and the study was conducted according to the principles embodied in the Helsinki Declaration for biomedical research involving human subjects.

Criteria for inclusion in the study were:

- Age $\geq 18$ years;

- Good general health, no pregnancy, no uncontrolled metabolic disorders;

- Presence of one hopeless premolar/molar tooth with endodontic treatment failure, root fracture, advanced periodontal disease, or endo-periodontal non-treatable lesion (Figure 1).

- Presence of a severe wall defect (absence of vestibular or lingual/palatal socket wall, or $>$ $50 \%$ missing vestibular or lingual/palatal socket wall) as shown by the radiographs and cone-beam computed tomography (CBCT) examination. 


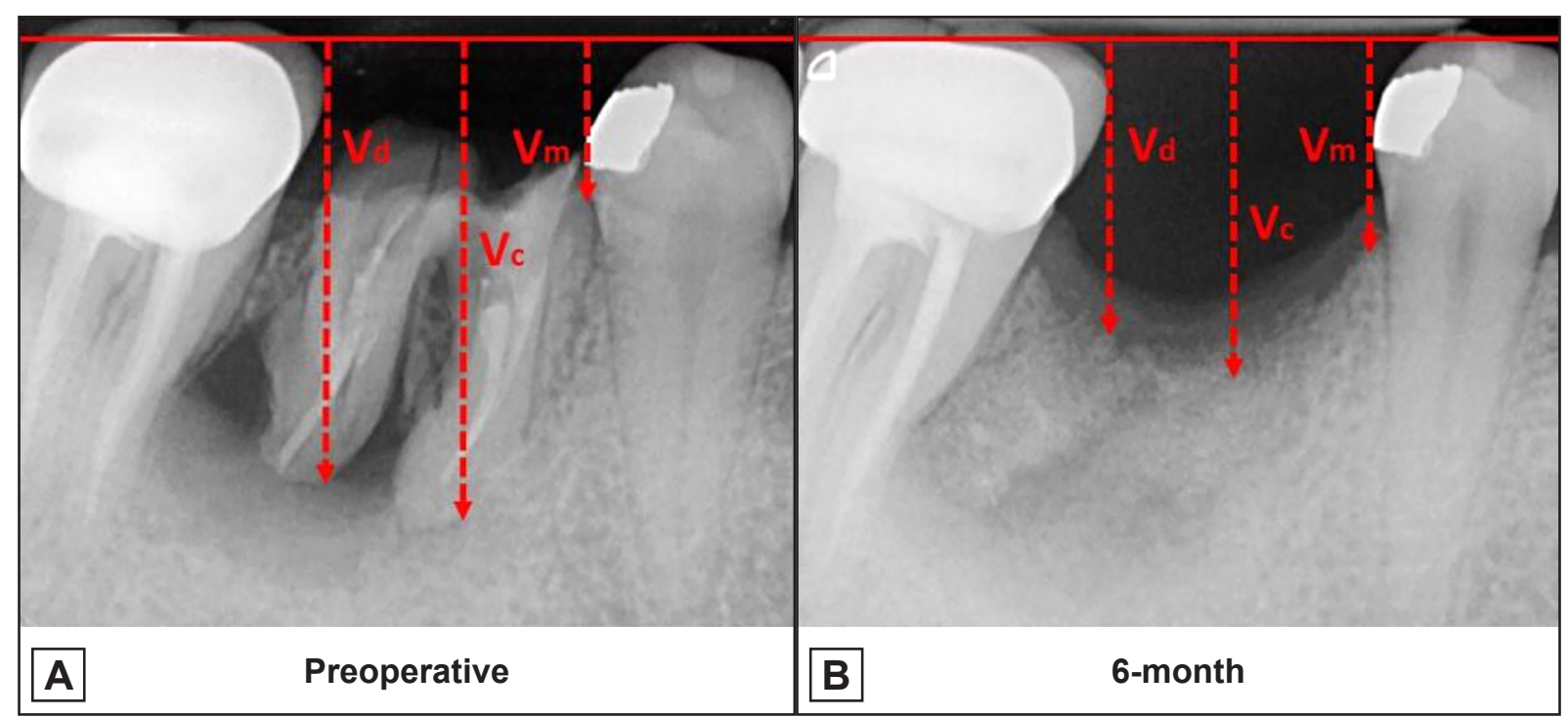

Figure 1. Intraoral periapical radiograph: $A=$ before grafting procedure; $B=6$ months after grafting procedure. $\mathrm{Vd}=$ vertical distal; $\mathrm{Vc}=$ vertical central; $\mathrm{Vm}=$ vertical mesial.

Exclusion criteria were:

- History of systemic diseases that contraindicate oral surgery;

- Long-term non-steroidal anti-inflammatory drug therapy;

- Oral bisphosphonate therapy;

- Pregnancy or lactation;

- Unwillingness to return for the follow-up examinations;

- Cigarette consumption $>10$ per day.

Treatments were performed by two different surgeons (RG, LT), who had previously undergone a calibration surgical session on a sample of 5 patients, treated with the same surgical technique and not included in the study. All patients were monitored and examined clinically every 2 weeks during the healing period according to standard routine treatments, and recalled after 6 months for re-examination.

In all patients, intraoral periapical radiographs were taken before extraction, immediately after extraction and grafting, and 6 months post treatment; while cone-beam computed tomography (CBCT) examination was carried-out before extraction and 6 months later.

At the first clinical examination, the following parameters were assessed: full mouth plaque score, full mouth bleeding score, pocket depth, number of sites with plaque, and number of sites with bleeding on probing. Tooth mobility according to Miller's classification was evaluated. Deep scaling and root planning with hand- and power-driven instruments were performed, and residual probing pocket depths and furcation involvement were reevaluated after 3 months. Non-surgical therapy was performed to eliminate or reduce inflammation and remove microbial plaque and calculus deposit around periodontal tissue and tooth surfaces. Three months after resolving the acute phase of inflammation, nonrestorable premolar/molar teeth were extracted.

\section{Radiographic examinations}

Intraoral periapical radiographs were performed immediately and 6 months after surgery, with a paralleling technique using a Rinn film holder with a rigid film-object X-ray source. For the radiograph procedures, a silicone index material was fixated to the residual dentition and a radiograph holder was constructed for each patient. This technique ensured that the same position of the radiograph film could be reproduced at each visit and that the radiograph angle would not deviate. The radiographs were taken in high resolution mode (Vista Scan Durr Dental, Durr Dental Italy S.r.l, Muggiò/Milan, Italy) with a dental X-ray machine (TM 2002 Planmeca Proline CC, Planmeca Group Helsinki, Finland) equipped with a long tube that operated at $70 \mathrm{Kw} / 7.5 \mathrm{~mA}$. Specialized software (DBSWIN software, Durr Dental Italy S.r.l, Muggiò/ Milan, Italy) was used for linear measurements. The vertical measurements were assessed at the mesial, central, and distal aspects of the extraction socket (Figure 1). The difference in radiographic vertical defect depths before extraction and after 6 months was calculated as the distance between the most coronal part of the adjacent teeth to the most apical part of the residual alveolar bone. CBCT examinations were performed before tooth extractions and after 6 months (Figure 2 - 4). A CBCT machine operating at $120 \mathrm{kVp}$ and $5 \mathrm{~mA}$ with a resolution of $0.1 \times 0.1 \times 0.1 \mathrm{~mm}^{3}$, and software with a slice thickness of $0.1 \mathrm{~mm}$ were used. 


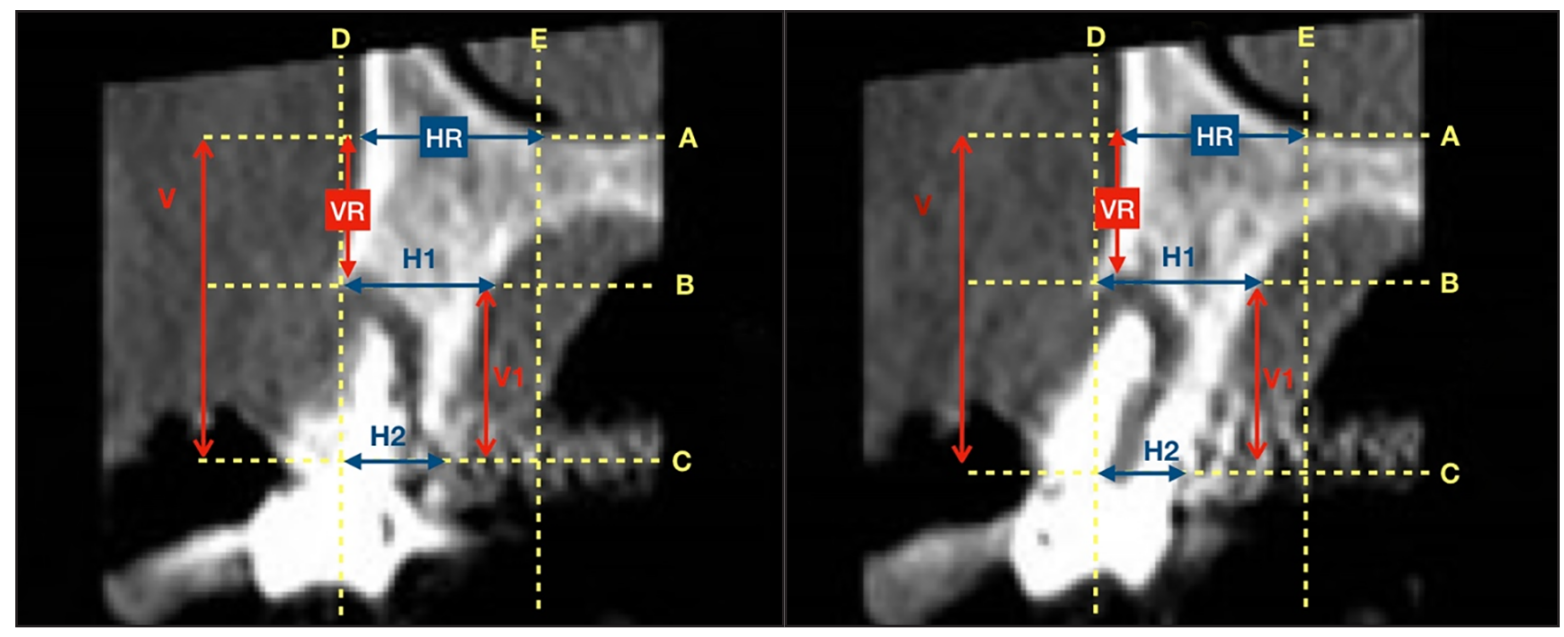

Figure 2. Cone-beam computed tomography scans before grafting procedure. $\mathrm{A}=$ line drawn at the level of the maxillary sinus floor; $\mathrm{B}=$ line drawn at the level of the most apical part of the residual alveolar bone wall; $\mathrm{C}=$ line drawn at the level of the most coronal aspect of the residual alveolar bone wall; $\mathrm{D}=$ line drawn at the vestibular aspect of the residual alveolar bone wall; $\mathrm{E}=$ line drawn at the lingual $/ \mathrm{palatal}$ aspect of the residual alveolar bone wall; V-VR = vertical; HR-H1 = horizontal/apical; HR-H2 = horizontal/coronal.

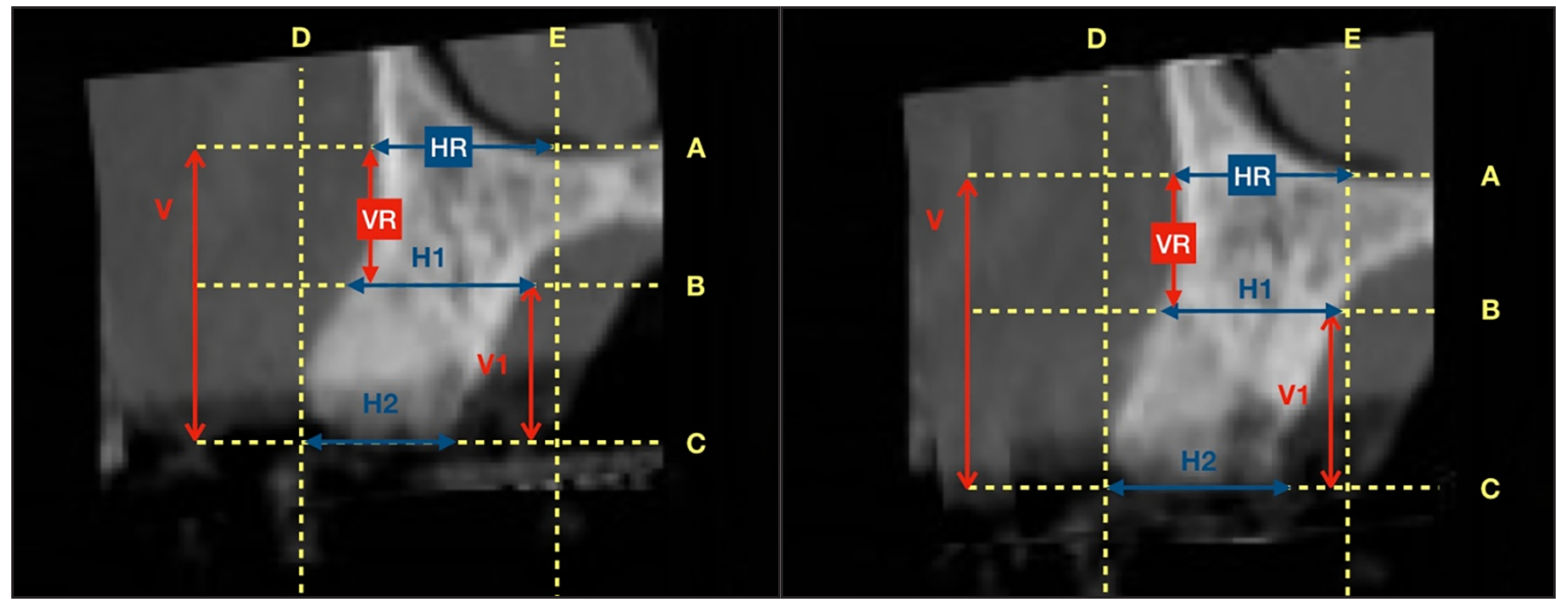

Figure 3. Cone-beam computed tomography scans 6 months after grafting procedure. $A=$ line drawn at the level of the maxillary sinus floor; $\mathrm{B}=$ line drawn at the level of the most apical part of the residual alveolar bone wall; $\mathrm{C}=$ line drawn at the level of the most coronal aspect of the residual alveolar bone wall; $\mathrm{D}=$ line drawn at the vestibular aspect of the residual alveolar bone wall; $\mathrm{E}=$ line drawn at the lingual/palatal aspect of the residual alveolar bone wall; $\mathrm{V}-\mathrm{VR}=$ vertical; HR-H1 = horizontal/apical; HR-H2 = horizontal/coronal.

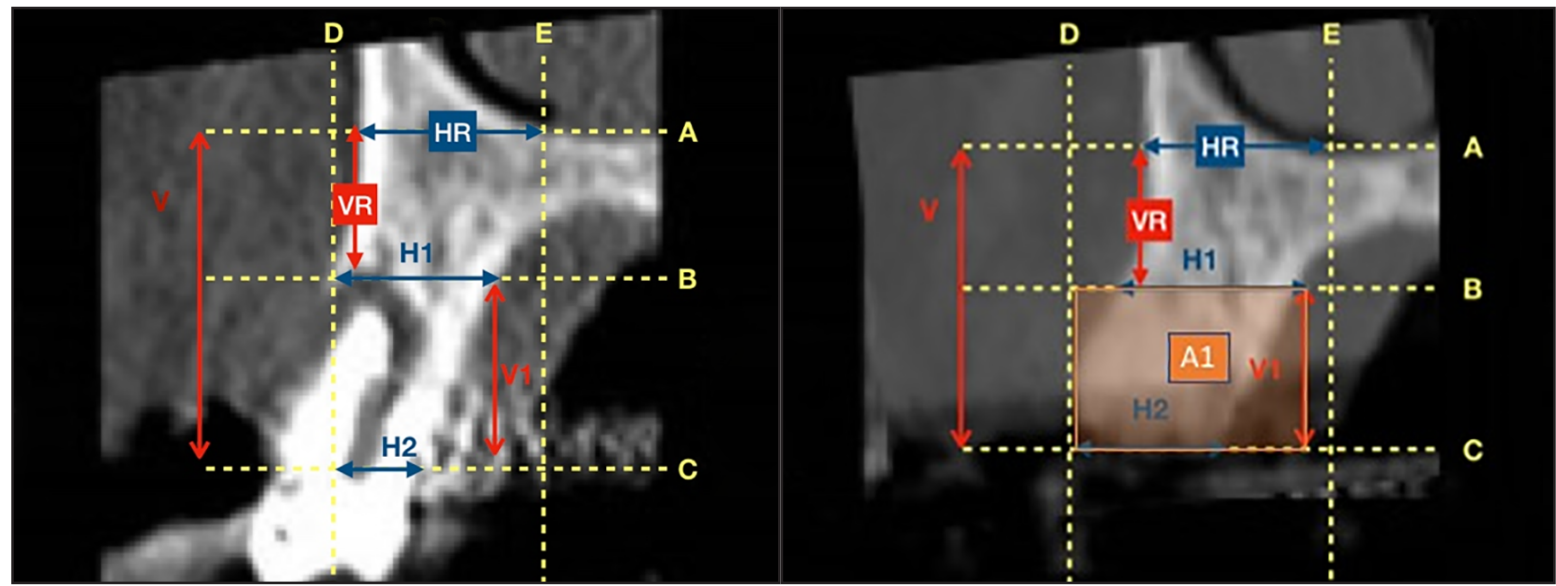

Figure 4. Example of area measured in cone-beam computed tomography scans before and 6 months after grafting procedure. A line drawn at the level of the maxillary sinus floor; $\mathrm{B}=$ line drawn at the level of the most apical part of the residual alveolar bone wall; $\mathrm{C}=$ line drawn at the level of the most coronal aspect of the residual alveolar bone wall; $\mathrm{D}=$ line drawn at the vestibular aspect of the residual alveolar bone wall; $\mathrm{E}=$ line drawn at the lingual/palatal aspect of the residual alveolar bone wall; V-VR = vertical; HR-H1 = horizontal/ apical; HR-H2 = horizontal/coronal. 


\section{Measurement technique used for CBCT scans}

In the first CBCT scan (baseline), in each sagittal section, 3 horizontal parallel straight lines were drawn at the level of the maxillary sinus floor (A), at the level of the most apical part of the residual alveolar bone wall (B), and at the level of the most coronal part of the residual alveolar bone wall (C). In each sagittal section, the distance (HR) was measured in $\mathrm{mm}$, and was chosen as a reference for the most vestibular straight vertical line (D) and the most palatal/lingual vertical straight line (E). D and $\mathrm{E}$ are perpendicular to $\mathrm{A}, \mathrm{B}$, and $\mathrm{C}$. The (VR) distance measure between line $\mathrm{A}$ and line $\mathrm{B}$ was used as a vertical refence. For horizontal measurements, the distance between the intersection point of lines $\mathrm{D} / \mathrm{C}$ and the most palatal/lingual aspect of the bone wall, was used to calculate the most apical horizontal measurement. The distance between the intersection point of lines $\mathrm{D} / \mathrm{B}$ and the most palatal/lingual aspect of the bone wall was used to calculate the most coronal horizontal measurement. For vertical measurements, the distance between the intersection point of lines $\mathrm{D} / \mathrm{B}$ (bottom of the socket) and the most coronal aspect of the bone crest, was used to calculate the vertical measurement V1 $=(\mathrm{V}-\mathrm{VR})$. In the second $\mathrm{CBCT}$ scan, at 6 month, similar horizontal and vertical segment measurements were obtained using corresponding sagittal section to the first CBCT scan (same sagittal sections of CBCT at different time points were identified by the same number). Taking these segments and their measurements as reference, the same lines of intersection were traced and measured. This allowed for comparative evaluation of $\mathrm{H} 1, \mathrm{H} 2$, and V1 pre- and postoperatively. The vertical change was considered as the difference of $\mathrm{V}-\mathrm{VR}$ measured in pre- and post-CBCT scan. The horizontal changes were considered as the difference between horizontal/apical (HR-H1) and horizontal/ coronal (HR-H2), measured at the two timepoints. Moreover, differences of the area enclosed between segments $\mathrm{H} 1, \mathrm{H} 2$, and $\mathrm{V} 1$, were measured in $\mathrm{mm}^{2}$, using the same specialized software and compared between the baseline (pre-operative) and at 6 months postoperative CBCT scan (Figure 4). Molar teeth with no preserved interseptal and furcal bone allowed for measurements at the centre of the extraction socket with no errors associated with radiographic interference.

All radiographic/tomographic measurements were carried out by a single trained examiner who had previously undergone a calibration session for radiographic/tomographic assessment on a sample of 5 patients treated with the same surgical technique and not included in the study (Kappa test $=0.924$; SE of kappa $=0.04 ; 95 \%$ confidence interval $=0.857$ to 1 ).

\section{Statistical analysis}

Data was presented as mean and standard deviation (M [SD]). Pearson's Chi-squared test was performed for comparison between mean vertical and horizontal bone levels, and mean areas enclosed within segments used for linear measurements. $\mathrm{P}<0.05$ was considered the threshold for statistical significance.

\section{Surgical protocol}

One hour prior to surgery, patients received $1 \mathrm{~g}$ amoxicillin and then $1 \mathrm{~g}$ twice a day for a week after the surgical procedure. Surgery was performed under local anaesthesia optocaine $20 \mathrm{mg} / \mathrm{mL}$ with adrenaline 1:80,000 (Molteni Dental, Italy). The following surgical procedure was performed: an intrasulcular incision, extended mesially and distally to the adjacent tooth, was made for surgical access. Multirooted teeth were sectioned with a Lindemann burr (Komet Inc., Lemgo, Germany) under copious irrigation with sterile saline. Each root was independently mobilized and carefully luxated. Attention was given not to damage the surrounding soft and hard tissues. All sockets were thoroughly curetted to remove granulation tissue, followed by rinsing with sterile saline. A periodontal probe was then utilized to explore the buccal and the lingual plate, and to determine the depth of the defect, which had to be in all cases $>50 \%$ of socket wall. After tooth removal and degranulation, a full thickness dissection was made in the vestibular, or palatal/lingual aspect of the flap, $2-3 \mathrm{~mm}$ beyond the apical extension of wall defect. Then in the vestibular aspect, the dissection was extended even more apically with split thickness technique in order to give enough mobility for repositioning coronally without flap tension. A highly porous anorganic porcine-derived bone mineral matrix, with particle size between 250 and $1000 \mu \mathrm{m}$ (Miner-Oss $\mathrm{XP}^{\circledR}$, BioHorizons, Birmingham, AL, USA), was placed and condensed to fill the extraction socket ensuring proper space maintenance to support the membrane. The mucoperiosteal flap was then repositioned and sutured with multiple horizontal mattress. In each site, the quantity of the xenograft was determined intra-operatively, taking care to fill the post-extractive alveolus until reaching vertically and horizontally the mesial and distal residual bone peak of adjacent teeth. No overfilling was performed. 
Table 1. Demographic data of patients, number and position of extracted teeth, and type of lesion

\begin{tabular}{c|c|c|c|c|c|c}
\hline $\begin{array}{c}\text { Tooth } \\
\#\end{array}$ & $\begin{array}{c}\text { Total } \\
\text { number }\end{array}$ & $\begin{array}{c}\text { Absence of } \\
\text { vestibular wall, } \\
\text { or }>\mathbf{5 0 \%} \text { missing }\end{array}$ & $\begin{array}{c}\text { Absence of palatal/ } \\
\text { lingual wall, } \\
\text { or }>\mathbf{5 0 \%} \text { missing }\end{array}$ & $\begin{array}{c}\text { Type of } \\
\text { lesion }\end{array}$ & $\begin{array}{c}\text { Patient 's age } \\
\text { (years) }\end{array}$ & $\begin{array}{c}\text { Patient's } \\
\text { sex }\end{array}$ \\
\hline 14 & - & - & - & - & - & - \\
\hline 15 & 2 & 2 & 1 & E - EP & $62-51$ & $\mathrm{M}$ - F \\
\hline 16 & 2 & 2 & - & EP - EP & $49-62$ & $\mathrm{M}-\mathrm{M}$ \\
\hline 17 & 1 & 1 & 1 & $\mathrm{P}$ & 57 & $\mathrm{~F}$ \\
\hline 24 & 1 & 1 & - & $\mathrm{P}$ & 36 & $\mathrm{M}$ \\
\hline 25 & 1 & 1 & 0 & $\mathrm{P}-\mathrm{EP}$ & $48-65$ & $\mathrm{M}-\mathrm{F}$ \\
\hline 26 & 2 & 2 & 0 & $\mathrm{EP}$ & 61 & $\mathrm{~F}$ \\
\hline 27 & 1 & 1 & - & - & - & - \\
\hline 34 & - & - & 1 & $\mathrm{P}-\mathrm{EP}$ & $52-66$ & $\mathrm{~F}-\mathrm{M}$ \\
\hline 35 & 2 & 2 & 1 & $\mathrm{P}-\mathrm{EP}$ & $48-59$ & $\mathrm{~F}-\mathrm{M}$ \\
\hline 36 & 2 & 2 & 0 & $\mathrm{P}-\mathrm{P}$ & $50-57$ & $\mathrm{M}-\mathrm{M}$ \\
\hline 37 & 2 & 2 & 0 & $\mathrm{EP}$ & 63 & $\mathrm{~F}$ \\
\hline 44 & 1 & 1 & 0 & $\mathrm{P}$ & 55 & $\mathrm{M}$ \\
\hline 45 & 1 & 1 & 1 & $\mathrm{P}-\mathrm{EP}$ & $42-60$ & $\mathrm{M}-\mathrm{F}$ \\
\hline 46 & 2 & 2 & - & - & - & - \\
\hline 47 & - & - & & & \\
\hline
\end{tabular}

$\mathrm{E}=$ endo $; \mathrm{P}=$ perio $; \mathrm{EP}=$ endo-perio $; \mathrm{M}=$ male $; \mathrm{F}=$ female.

A resorbable membrane, Mem-Lok Pliable ${ }^{\circledR}$ (BioHorizons, Birmingham, AL, USA) was placed covering the grafted extraction socket, taking care to extend one border of membrane beyond the apical limit of wall defect. Stabilization of the membrane and the underlying graft material was achieved by using horizontal mattress sutures (4-0 vicryl sutures, Ethicon, Somerville, NJ, USA), extending from the apical portion of the facial periosteum to the palatal aspect of the flap. Final tissue adaptation was achieved by means of multiple interrupted sutures without obtaining primary closure of the wound margins. The sutures were removed after 7 to 10 days, and signs of complications were checked. Twentyfour hours after the procedure, topical application of iodopovidone (iodine at $10 \%$ ) gel (Betadine ${ }^{\circledR}$ Meda Pharma, Milano, Italy) with a cotton swab to the site twice daily for 1 month was advised. The patient was asked to refrain from chewing on the surgical side and to perform gentle plaque removal from the site for the first week. After 1 week, the patient was instructed to perform meticulous plaque control at the site using gentle brushing and chemical plaque control with $0.12 \%$ chlorhexidine.

\section{RESULTS}

Demographic information of patients, number and position of extracted teeth, and type of lesion, are reported in Table 1. Mean changes in vertical heights measured using intraoral periapical radiographs at distal, central, and mesial aspects of extraction sockets are shown in Table 2. Mean vertical bone gains detected at the distal, central and mesial aspects of the extraction sockets were $3.5(1.1) \mathrm{mm}, 8.2$ (2.1) $\mathrm{mm}$, and $3.9(1.7) \mathrm{mm}$, respectively. Mean changes in vertical height and in horizontal width detected in CBCT scans are shown in Table 3. In CBCT scans, the mean vertical bone gain was $4.5(0.4) \mathrm{mm}$, and the mean horizontal bone gain at the most apical and most coronal aspects were $0.5(0.1) \mathrm{mm}, 6.5(0.9)$ $\mathrm{mm}$, respectively. The difference of area enclosed within segments $\mathrm{H} 1, \mathrm{H} 2$, and $\mathrm{V} 1$, between pre- and postoperative CBCT was $61.8 \mathrm{~mm}^{2}$. In all examined defects, mean vertical and horizontal bone levels showed a statistically significant increase $(\mathrm{P}<0.05)$ at 6 months after extraction, without difference between maxillary and mandibular sites.

Table 2. Vertical distances $(\mathrm{mm})$ measured in intraoral radiographic images

\begin{tabular}{l|c|c|c}
\hline & Before & $\begin{array}{c}\text { 6-month } \\
\text { postoperative }\end{array}$ & \multirow{2}{*}{ P significance $^{\text {a }}$} \\
\cline { 2 - 3 } & Mean (SD) & Mean (SD) & \\
\hline Vertical distal & $13.6(2.3)$ & $10.1(3.4)$ & $<0.05$ \\
\hline Vertical central & $20.7(3.4)$ & $12.5(2.8)$ & $<0.05$ \\
\hline Vertical mesial & $12.7(2.8)$ & $8.8(2.5)$ & $<0.05$ \\
\hline
\end{tabular}

astatistically significant at the level $\mathrm{P}<0.05$, Pearson's Chi-squared test.

$\mathrm{SD}=$ standard deviation 
Table 3. Vertical and horizontal distances $(\mathrm{mm})$ measured on CBCT scans

\begin{tabular}{l|c|c|c}
\hline & Before & $\begin{array}{c}\text { 6-month } \\
\text { postoperative }\end{array}$ & \multirow{2}{*}{ P significance $^{\text {a }}$} \\
\cline { 2 - 3 } & Mean (SD) & Mean (SD) & \\
\hline Vertical & $11.1(2.4)$ & $15.6(2.8)$ & $<0.05$ \\
\hline Horizontal/apical & $1.4(0.3)$ & $1.9(0.4)$ & $<0.05$ \\
\hline Horizontal/coronal & $1.8(0.2)$ & $8.3(1.1)$ & $<0.05$ \\
\hline Area $\left(\mathrm{mm}^{2}\right)$ & $17.76(4.1)$ & $79.56(10.4)$ & $<0.05$ \\
\hline
\end{tabular}

a Statistically significant at the level $\mathrm{P}<0.05$, Pearson's Chi-squared test.

$\mathrm{CBCT}=$ cone-beam computed tomography $\mathrm{SD}=$ standard deviation

\section{DISCUSSION}

The presence of periodontal disease, periapical pathology, and/or root fracture, often result in bone loss prior to tooth removal [3]. When associated with physiological bone reabsorption and remodelling, the aforementioned issues lead to additional bone volume reduction after tooth extraction. The 2012 Osteology Consensus Report [9], indicated RPTs as a mean of counteracting post-extraction volume loss, and of maintaining a stable ridge volume for optimizing subsequent implant placement. However, these procedures could result less effective in posterior areas in presence of extraction sockets with severe wall defects. A recent literature review with meta-analysis of Iocca at al. [10], indicated that both xenografts and autologous bone marrow were superior to "no graft" when multiple treatments were compared. This data confirmed conclusions of previous literature reviews, reporting the positive effect of RPTs on the prevention of post-extraction alveolar ridge volume loss compared to tooth extraction alone [5-12]. All the reviews highlighted an important limitation related to methodological and clinical heterogeneity such as the socket's location and morphology. This raises concerns on the possibility of generating inconsistent conclusions that may over- or under-estimate the therapeutic potential of specific extraction socket augmentation techniques, especially in posterior areas with severe wall defects. Since CBCT scans have been demonstrated to be effective in quantifying bone volume [31-32], the present study aimed to evaluate radiographically the effectiveness of RPT with a porcine-derived bone graft and a low resorption rate collagen membrane, in premolar/molar extraction sites with severe wall defects. The evaluation of the radiographic/ tomographic measurements underlines the efficacy of the surgical protocol performed in the present study.
Both the vertical and horizontal dimensions showed a statistically significant increase at 6 months. In particular, in the CBCT scans the mean vertical bone gain was $4.5(0.4) \mathrm{mm}$, and the mean horizontal bone gain was $3.5(0.5) \mathrm{mm}$. To our knowledge, few studies reported data related to premolar/molar extraction sockets with severe wall defects. A study by Rasperini et al. [33], conducted in the posterior area, reported data only for preserved sockets with four walls intact, while studies of Sisti et al. [34], Barone et al. [35], and Wang et al. [36], although related to severely resorbed extraction sockets, reported data only for sites in the frontal area. Thus, a comparison of this study's results with literature data is not possible. A systematic literature review with meta-analysis [4] reported on the difference in treatment effect based on variations in RPTs. Results indicated that flap elevation, use of a barrier membrane, and primary closure, present a beneficial effect on augmentation of vertical alveolar bone height and horizontal bone width. Findings of the present study are partially in agreement with these data, since they showed that the secondary soft tissue closure and membrane exposure don't affect the efficacy of RPT. This result could be linked to physical and chemical features of the collagen membrane used in the present study which, in a preclinical study [37] showed to be characterized by a resorption rate of 12/16 weeks at the intraoral implantation site, eliciting a low inflammatory and foreign body giant cell response. It is hypothesized that the low degree of inflammation and foreign body response may result in enhanced tissue integration and improved wound healing in terms of minimizing scar-like tissue formation [37]. Moreover, in the same in vitro study the collagen membrane showed significantly higher suture pull out strength, higher stability and higher level of intermolecular crosslinking compared to conventional collagen membranes. It is possible to assume that the stiffness of the resorbable collagen membrane could have improved the stability throughout the graft material, and consequently, the quantity of regenerated bone due to reduced micromotion of the graft particles. It is known that micromovements between bone and any implanted grafted material prevent bone formation and may lead to mesenchymal cell differentiation to fibroblasts instead of osteoblasts, resulting in the development of fibrous tissue [38].

The final goal of any grafting procedure should be the achievement of $100 \%$ living bone and a reactive tissue able to undergo a sustained state of remodelling. Excluding the autologous bone, which represents the ideal graft material, [4] extraction sites grafted with xenografts exhibited less bone volume loss compared 
to sites with alloplasts (hydroxy-apatite, tricalcium phosphate, and calcium sulphate) [4]. In the present study, the healing process of grafted extraction sockets was not evaluated histologically. However, a previous histological and histomorphometric study [23] on extraction sites without severe wall defects, treated with the same biomaterial used in the present study, reported a mean percentage of newly formed bone of $57.43(4.8) \%$, and a mean percentage of residual graft particles of $16.57(2.8) \%$ after 6 months. To date, controversy remains whether residual xenogenic graft particles present in biopsy samples harvested from regenerated extraction sockets may influence or interfere with the osseointegration process of dental implants, and bone-to-implant contact [39]. The degradation time and ultimate fate of many commercially available xenogenic grafting materials at various grafted sites is also not fully understood. The degradation of xenogenic bone depends on the processing that can cause variations in physicochemical properties, hydrophilicity, and viscoelasticity of the material [40]. More specifically, the high temperature sintering method leads to increased crystalline minerals, which imparts a lower degradation rate compared to low temperature and chemical treatment methods. Additionally, the degradation process is influenced by pore morphology, degree of porosity, pore interconnection, and granule size distribution [41]. A decrease in pore connectivity could possibly influence the osteoblasts' penetration through the porous structure. The degree of angiogenesis and the resulting flux of nutrient and of oxygen could also be lower [42]. The porcinederived bone used in the current study is produced by low temperature treatment method with chemical removal of organic components. It presents a mean pore size of $474.26(76.2) \mu \mathrm{m}$, a mean strut thickness of $121.76(21.9) \mu \mathrm{m}$, a mean pore connectivity of 88 $95 \%$ and a crystal size of approximately $10 \mu \mathrm{m}$ [43], which are similar to those of human bone [44].
The current study reported preliminary clinical and radiographic findings at 6 months, but it will follow the patients for 3 years after implant placement. Therefore, only the subsequent histological analyses, obtained from the biopsies at implant sites, could provide a better understanding of the results obtained. One limitation of the current study is the low number of patients enrolled. Another limitation is the absence of a control group. However, it is important to stress that, since the predictability and expected outcome of ridge augmentation in sockets with severely deficient plates in the molar area remains unknown, case series such as this one often represent the first line of clinical evidence, which underscores its clinical value.

\section{CONCLUSIONS}

Within the limits of the present study it is possible to conclude that porcine-derived bone graft covered by a collagen membrane can support significant vertical and horizontal bone gain in posterior post-extraction sockets with severe wall defects. With this treatment, the clinical quantity of bone regenerated ensures successful implant placement.

\section{ACKNOWLEDGMENTS AND DISCLOSURE STATEMENTS}

The authors report no conflicts of interest related to this study. The study was supported by BioHorizons, Birmingham, AL, USA, who provided the materials.

Renzo Guarnieri and Luca Testarelli contributed substantially to the research design and draft of the manuscript. Dario Di Nardo, Gianni Di Giorgio, Gabriele Miccoli worked on data acquisition and analysis. All authors helped with data interpretation and critical review of the manuscript.

\section{REFERENCES}

1. Van der Weijden F, Dell'Acqua F, Slot DE. Alveolar bone dimensional changes of post-extraction sockets in humans: a systematic review. J Clin Periodontol. 2009 Dec;36(12):1048-58. [Medline: 19929956] [doi: 10.1111/j.1600-051X.2009.01482.x]

2. Trombelli L, Farina R, Marzola A, Bozzi L, Liljenberg B, Lindhe J. Modeling and remodeling of human extraction sockets. J Clin Periodontol. 2008 Jul;35(7):630-9. [Medline: 18498382] [doi: 10.1111/j.1600-051X.2008.01246.x]

3. Walker KF, Lappin DF, Takahashi K, Hope J, Macdonald DG, Kinane DF. Cytokine expression in periapical granulation tissue as assessed by immunohistochemistry. Eur J Oral Sci. 2000 Jun;108(3):195-201. [Medline: 10872989] [doi: 10.1034/j.1600-0722.2000.108003195.x]

4. Avila-Ortiz G, Elangovan S, Kramer KW, Blanchette D, Dawson DV. Effect of alveolar ridge preservation after tooth extraction: a systematic review and meta-analysis. J Dent Res. 2014 Oct;93(10):950-8. [Medline: 24966231] [PMC free article: 4293706] [doi: 10.1177/0022034514541127] 
5. De Buitrago JG, Avila-Ortiz G, Elangovan S. Quality assessment of systematic reviews on alveolar ridge preservation. J Am Dent Assoc. 2013 Dec;144(12):1349-57. [Medline: 24282264] [doi: 10.14219/jada.archive.2013.0070]

6. De Risi V, Clementini M, Vittorini G, Mannocci A, De Sanctis M. Alveolar ridge preservation techniques: a systematic review and meta-analysis of histological and histomorphometrical data. Clin Oral Implants Res. 2015 Jan;26(1):50-68. [Medline: 27007188] [doi: 10.1111/clr.12288]

7. Horváth A, Mardas N, Mezzomo LA, Needleman IG, Donos N. Alveolar ridge preservation. A systematic review. Clin Oral Investig. 2013 Mar;17(2):341-63. [Medline: 22814758] [doi: 10.1007/s00784-012-0758-5]

8. Mardas N, Trullenque-Eriksson A, MacBeth N, Petrie A, Donos N. Does ridge preservation following tooth extraction improve implant treatment outcomes: a systematic review: Group 4: Therapeutic concepts \& methods. Clin Oral Implants Res. 2015 Sep;26 Suppl 11:180-201. [Medline: 26078004] [doi: 10.1111/clr.12639]

9. Hämmerle $\mathrm{CH}$, Araújo MG, Simion M; Osteology Consensus Group 2011. Evidence-based knowledge on the biology and treatment of extraction sockets. Clin Oral Implants Res. 2012 Feb;23 Suppl 5:80-2. [Medline: 22211307] [doi: 10.1111/j.1600-0501.2011.02370.x]

10. Iocca O, Farcomeni A, Pardiñas Lopez S, Talib HS. Alveolar ridge preservation after tooth extraction: a Bayesian Network meta-analysis of grafting materials efficacy on prevention of bone height and width reduction. J Clin Periodontol. 2017 Jan;44(1):104-114. [Medline: 27712001]

11. Vignoletti F, Matesanz P, Rodrigo D, Figuero E, Martin C, Sanz M. Surgical protocols for ridge preservation after tooth extraction. A systematic review. Clin Oral Implants Res. 2012 Feb;23 Suppl 5:22-38. [Medline: 22211304] [doi: 10.1111/j.1600-0501.2011.02331.x]

12. Vittorini Orgeas G, Clementini M, De Risi V, de Sanctis M. Surgical techniques for alveolar socket preservation: a systematic review. Int J Oral Maxillofac Implants. 2013 Jul-Aug;28(4):1049-61. [Medline: 23869363] [doi: 10.11607/jomi.2670]

13. Retzepi M, Donos N. Guided Bone Regeneration: biological principle and therapeutic applications. Clin Oral Implants Res. 2010 Jun;21(6):567-76. [Medline: 20666785] [doi: 10.1111/j.1600-0501.2010.01922.x]

14. Bunyaratavej P, Wang HL. Collagen membranes: a review. J Periodontol. 2001 Feb;72(2):215-29. [Medline: 11288796] [doi: 10.1902/jop.2001.72.2.215]

15. Dimitriou R, Mataliotakis GI, Calori GM, Giannoudis PV. The role of barrier membranes for guided bone regeneration and restoration of large bone defects: current experimental and clinical evidence. BMC Med. 2012 Jul 26;10:81. [Medline: 22834465] [PMC free article: 3423057] [doi: 10.1186/1741-7015-10-81]

16. de Misquita MR, Bentini R, Goncalves F. The performance of bone tissue engineering scaffolds in in vivo animal models: A systematic review. J Biomater Appl. 2016 Nov;31(5):625-636. [Medline: 27334129] [doi: 10.1177/0885328216656476]

17. Esposito M, Grusovin MG, Coulthard P, Worthington HV. The efficacy of various bone augmentation procedures for dental implants: a Cochrane systematic review of randomized controlled clinical trials. Int J Oral Maxillofac Implants. 2006 Sep-Oct;21(5):696-710. [Medline: 17066630 ]

18. Urist MR. Bone: formation by autoinduction. Science. 1965 Nov 12;150(3698):893-9. [Medline: 5319761] [doi: $10.1126 /$ science. 150.3698 .893 ]

19. Burchardt H. The biology of bone graft repair. Clin Orthop Relat Res. 1983 Apr;(174):28-42. [Medline: 6339139] [doi: 10.1097/00003086-198304000-00005]

20. Misch CE, Dietsh F. Bone-grafting materials in implant dentistry. Implant Dent. 1993 Fall;2(3):158-67. [Medline: 8142935] [doi: 10.1097/00008505-199309000-00003]

21. Barone A, Aldini NN, Fini M, Giardino R, Calvo Guirado JL, Covani U. Xenograft versus extraction alone for ridge preservation after tooth removal: a clinical and histomorphometric study. J Periodontol. 2008 Aug;79(8):1370-7. [Medline: $\underline{18672985}$ ] [doi: 10.1902/jop.2008.070628]

22. Barone A, Toti P, Quaranta A, Alfonsi F, Cucchi A, Negri B, Di Felice R, Marchionni S, Calvo-Guirado JL, Covani U, Nannmark U. Clinical and Histological changes after ridge preservation with two xenografts: preliminary results from a multicentre randomized controlled clinical trial. J Clin Periodontol. 2017 Feb;44(2):204-214. [Medline: 27883211] [doi: $10.1111 /$ jcpe.12655]

23. Guarnieri R, Testarelli L, Stefanelli L, De Angelis F, Mencio F, Pompa G, Di Carlo S. Bone Healing in Extraction Sockets Covered With Collagen Membrane Alone or Associated With Porcine-Derived Bone Graft: a Comparative Histological and Histomorphometric Analysis. J Oral Maxillofac Res. 2017 Dec 31;8(4):e4. [Medline: 29435206] [PMC free article: 5806041] [doi: 10.5037/jomr.2017.8404]

24. Guarnieri R, Stefanelli L, De Angelis F, Mencio F, Pompa G, Di Carlo S. Extraction Socket Preservation Using Porcine-Derived Collagen Membrane Alone or Associated with Porcine-Derived Bone. Clinical Results of Randomized Controlled Study. J Oral Maxillofac Res. 2017 Sep 30;8(3):e5. [Medline: 29142657] [PMC free article: 5676315] [doi: 10.5037/jomr.2017.8305]

25. Barone A, Aldini NN, Fini M, Giardino R, Calvo Guirado JL, Covani U. Xenograft versus extraction alone for ridge preservation after tooth removal: a clinical and histomorphometric study. J Periodontol. 2008 Aug;79(8):1370-7. [Medline: 18672985] [doi: 10.1902/jop.2008.070628] 
26. Barone A, Ricci M, Covani U, Nannmark U, Azarmehr I, Calvo-Guirado JL. Maxillary sinus augmentation using prehydrated corticocancellous porcine bone: hystomorphometric evaluation after 6 months. Clin Implant Dent Relat Res. 2012 Jun;14(3):373-9. [Medline: 20491813] [10.1111/j.1708-8208.2010.00274.x]

27. Kivovics M, Szabó BT, Németh O, Tari N, Dőri F, Nagy P, Dobó-Nagy C, Szabó G. Microarchitectural study of the augmented bone following ridge preservation with a porcine xenograft and a collagen membrane: preliminary report of a prospective clinical, histological, and micro-computed tomography analysis. Int J Oral Maxillofac Surg. 2017 Feb;46(2):250-260. [Medline: 27839628] [doi: 10.1016/j.ijom.2016.10.010]

28. Nannmark U, Sennerby L. The bone tissue responses to prehydrated and collagenated cortico-cancellous porcine bone grafts: a study in rabbit maxillary defects. Clin Implant Dent Relat Res. 2008 Dec;10(4):264-70. [Medline: 18241216] [doi: $10.1111 / \mathrm{j} .1708-8208.2007 .00080 . \mathrm{x}$ ]

29. Orsini G, Scarano A, Piattelli M, Piccirilli M, Caputi S, Piattelli A. Histologic and ultrastructural analysis of regenerated bone in maxillary sinus augmentation using a porcine bone-derived biomaterial. J Periodontol. 2006 Dec;77(12):1984-90. [Medline: 17209782] [doi: 10.1902/jop.2006.060181]

30. Pagliani L, Andersson P, Lanza M, Nappo A, Verrocchi D, Volpe S, Sennerby L. A collagenated porcine bone substitute for augmentation at Neoss implant sites: a prospective 1-year multicenter case series study with histology. Clin Implant Dent Relat Res. 2012 Oct;14(5):746-58. [Medline: 20977615] [doi: 10.1111/j.1708-8208.2010.00314.x]

31. Ganz SD. Conventional CT and cone beam CT for improved dental diagnostics and implant planning. Dent Implantol Update. 2005 Dec;16(12):89-95. [Medline: 16422471]

32. Quirynen M, Lamoral Y, Dekeyser C, Peene P, van Steenberghe D, Bonte J, Baert AL. CT scan standard reconstruction technique for reliable jaw bone volume determination. Int J Oral Maxillofac Implants. 1990 Winter;5(4):384-9. [Medline: 2094657]

33. Rasperini G, Canullo L, Dellavia C, Pellegrini G, Simion M. Socket grafting in the posterior maxilla reduces the need for sinus augmentation. Int J Periodontics Restorative Dent. 2010 Jun;30(3):265-73. [Medline: 20386783]

34. Sisti A, Canullo L, Mottola MP, Covani U, Barone A, Botticelli D. Clinical evaluation of a ridge augmentation procedure for the severely resorbed alveolar socket: multicenter randomized controlled trial, preliminary results. Clin Oral Implants Res. 2012 May;23(5):526-35. [Medline: 22150876] [doi: 10.1111/j.1600-0501.2011.02386.x]

35. Barone A, Ricci M, Romanos GE, Tonelli P, Alfonsi F, Covani U. Buccal bone deficiency in fresh extraction sockets: a prospective single cohort study. Clin Oral Implants Res. 2015 Jul;26(7):823-30. [Medline: 24684275] [doi: $10.1111 /$ clr.12369]

36. Wang CW, Koo S, Kim D, Machtei EE. Negotiating the severely resorbed extraction site: a clinical case report with histologic sample. Quintessence Int. 2014 Mar;45(3):203-8. [Medline: 24570987]

37. Shu-Tung L, Debbie Y, Drew M, Natsuyo SL. A Comparative Study of a New Porcine Collagen Membrane to Bio-Gide ${ }^{\circledR}$. Science, Technology, Innovation 2015 Feb;1-5. [URL: https://www.osseonews.com]

38. Buser D, Dahlin C, Schenk RK. Guided Bone Regeneration in Implant Dentistry. London: Quintessence Publishing; 1995. p. 49-100.

39. Schlegel AK, Donath K. BIO-OSS--a resorbable bone substitute? J Long Term Eff Med Implants. 1998;8(3-4):201-9. [Medline: 10186966]

40. Riachi F, Naaman N, Tabarani C, Aboelsaad N, Aboushelib MN, Berberi A, Salameh Z. Influence of material properties on rate of resorption of two bone graft materials after sinus lift using radiographic assessment. Int J Dent. 2012;2012:737262. [Medline: 22899930] [PMC free article: 3415107] [doi: 10.1155/2012/737262]

41. Lapczyna H, Galea L, Wüst S, Bohner M, Jerban S, Sweedy A, Doebelin N, van Garderen N, Hofmann S, Baroud G, Müller R, von Rechenberg B. Effect of grain size and microporosity on the in vivo behaviour of $\beta$-tricalcium phosphate scaffolds. Eur Cell Mater. 2014 Oct 23;28:299-319. [Medline: 25340808]

42. Yamada Y, Tamura T, Hariu K, Asano Y, Sato S, Ito K. Angiogenesis in newly augmented bone observed in rabbit calvarium using a titanium cap. Clin Oral Implants Res. 2008 Oct;19(10):1003-9. [Medline: 18828816] [doi: $10.1111 / \mathrm{j} .1600-0501.2008 .01554 . \mathrm{x}$ ]

43. Guarnieri R, DeVilliers P, Grande M, Stefanelli LV, Di Carlo S, Pompa G. Histologic evaluation of bone healing of adjacent alveolar sockets grafted with bovine- and porcine-derived bone: a comparative case report in humans. Regen Biomater, 2017 Mar 1;4(2):125-8. [doi: 10.1093/rb/rbx002]

44. Parfitt AM, Drezner MK, Glorieux FH, Kanis JA, Malluche H, Meunier PJ, Ott SM, Recker RR. Bone histomorphometry: standardization of nomenclature, symbols, and units. Report of the ASBMR Histomorphometry Nomenclature Committee. J Bone Miner Res. 1987 Dec;2(6):595-610. [Medline: 3455637] [doi: 10.1002/jbmr.5650020617] 


\section{To cite this article:}

Guarnieri R, Di Nardo D, Di Giorgio G, Miccoli G, Testarelli L.

Effectiveness of Xenograft and Porcine-Derived Resorbable Membrane in Augmentation of Posterior Extraction Sockets with a Severe Wall Defect. A Radiographic/Tomographic Evaluation

J Oral Maxillofac Res 2019;10(1):e3

URL: http://www.ejomr.org/JOMR/archives/2019/1/e3/v10n1e3.pdf

doi: $\underline{10.5037 / \text { jomr.2019.10103 }}$

Copyright (C) Guarnieri R, Di Nardo D, Di Giorgio G, Miccoli G, Testarelli L. Published in the JOURNAL OF ORAL \& MAXILLOFACIAL RESEARCH (http://www.ejomr.org), 31 March 2019.

This is an open-access article, first published in the JOURNAL OF ORAL \& MAXILLOFACIAL RESEARCH, distributed under the terms of the Creative Commons Attribution-Noncommercial-No Derivative Works 3.0 Unported License, which permits unrestricted non-commercial use, distribution, and reproduction in any medium, provided the original work and is properly cited. The copyright, license information and link to the original publication on (http://www.ejomr.org) must be included. 